УДК 623:069(477)

DOI: 10.33099/2707-1383-2020-38-4-210-219

Воронов С.О., завідуючий філією,

Начіональний військово-історичний

музей України - Центральний військово-

морський музей Украйни (м. Київ, Украӥна)

\title{
ПІДВОДНО-АРХЕОЛОГІЧНІ ДОСЛІДЖЕННЯ В УКРАЇНІ В СФЕРІ МУЗЕСФІКАЦЇ̈
}

Спочатку, коротка підводно-археологічна автобіографія Чорного моря. 230-60 млн років назад, під час Юрського періоду, між Тихим і Атлантичним океаном (об'єднуючи їх) знаходилося солоне море Тетіс. Море мало величезну площу від Гібралтару на заході, i, включаючи сучасні Чорне і Азовське моря, простягалося до гір Паміру, Гімалаїв і Тянь-Шаню на сході. В районі сучасного Чорного моря вулканічна діяльність розпочалася біля 70 млн років назад в Тріасовий період. Саме завдяки вулканам Чорне море отримало першу сушу - декілька острівців, які на сьогодні є складовою частиною гір Кримського півострова. Десь ближче до середини третичного періоду, біля 30 млн років назад, в ході процесів гороутворення, море Тетіс багаточисленними рухами земної кори було відокремлене спочатку від Тихого, а потім і від Атлантичного океану. Біля 7-5 млн років назад, в міоцен, створення Кавказьких, Карпатських і Альпійських гір зменшило площу моря Тетіс. Утворилися декілька морів з незначною солоністю.

Територія сучасних Чорного, Азовського, Каспійського і Аральського морів входила в зону так званого Сарматського моря. Це море простягалося від центральних Альп до західної стіни Тянь-Шаню. Впадіння в Сарматське море значної кількості прісної води річок Дніпра, Дунаю, Південного Бугу, Волги, Сирдар’ї, Амудар'ї і багатьох малих, суттєво зменшили рівень солоності моря і повністю змінили флору і фауну. Біля 3-2 млн років назад, в самому кінці міоцену, Сарматське море значно зменшується і знову отримує зв'язок з океаном. Знову в водоймі відновлюється морська флора і фауна. А море отримує назву Меотичного. 1,5 млн років назад, в пліоцені, з'єднання Меотичного моря з океаном знову призупиняється, і на його місці з часом виникає майже прісне Понтичне озеро-море, територія якого вміщає сучасні площі Чорного, Азовського і Каспійського морів.

Біля 1 млн років назад настав льодовиковий період, який своєю тектонічною діяльністю розділив Чорне і Каспійське моря. 150-100 тисяч років назад створюються протоки Босфор і Дарданели, які з'єднують пра-Чорне море з Середземним і вже в який раз змінюють флору і фауну з річкової на морську. Але, біля 20-18 тисяч років назад протоки призупиняють пропуск солоної води і внаслідок глобального танення льодовиків Чорне море знову стає прісноводним. I, нарешті, 7-5 тисяч років назад (існує навіть точна цифра - 7150 років) внаслідок глобального потепління і танення льодовиків, води поступово проривають Босфор і Дарданели, і Чорне море отримує сучасний вигляд. Вірогідно, що останній етап становлення Чорного моря проходив вже за участі людини. I саме пошук слідів цих культур, які проживали на берегах Чорного моря в цей історичний період, і $є$ самою великою науковою інтригою і пригодою для 
археологів. Історіографія цієї гіпотези (праці античних авторів і легенди багатьох народів) потребують дуже серйозного підходу і обережності в дослідженні цієї теми.

Офіційна наука не заперечує, що на дні Чорного моря, в межах прадавнього узбережжя, на глибині приблизно 200 м можуть бути сліди життєдіяльності невідомих культур, які могли існувати 10-20 тисяч років назад. Доказами цього можуть бути і залишки поселень і міст, і сліди корабельних катастроф. I саме головне - Чорне море має природні можливості зберегти ці сліди в первозданному вигляді.

Багаточисленні зміни, які відбувалися в Чорному морі, починаючи з Юрського періоду, спровокували часті зміни солоності, що в свою чергу викликало масову загибель флори і фауни. В результаті цього замкнутий тип моря і його батометричні особливості і відсутність вертикальної циркуляції створили шар води, який містить сірко-во- день. В зв'язку з відсутністю в цьому шарі кисню, тут також відсутні і головні вороги археологів - мікроорганізми, які знищують органічні і не органічні пам'ятники. За інформацією Морського гідрофізичного інституту НАН України цей шар займає біля 87\% обсягу Чорного моря. Сірко-водень розповсюджується в шарі води від дна до глибин 150-200 м. Існують факти про його підйоми на глибину до 50-70 м і навіть на поверхню моря. Безумовно, наявність сірко-водню в Чорному морі не $є$ чимось виключним. Він зустрічається в глибинних впадинах Каспійського, Балтійського i Аравійського морів. Але, жодне із згаданих морів не має такої яскравої і наповненої історії яка містить події від народження людства до сучасності. Саме тому Чорне море є унікальним природним музеєм i apхеологічним заповідником, в якому навіть античні кораблі можуть зберігатися в цілому вигляді.

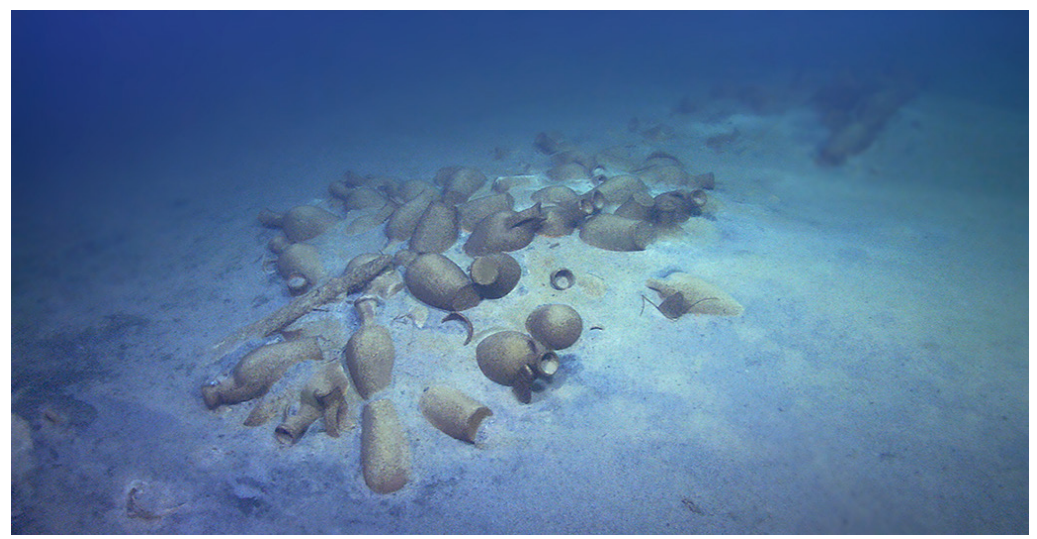

Фото 1. Місце загибелі не ідентифікованого малого «латинського вітрильника»е епохи Візантії (IX-X ст.). Виявлений за 19 миль на S-W від мису Херсонес Українсько-Американською експедицією 2006 р.

(С. Воронов, Р. Баллард). Фото С. Воронова

Вже 3 XIX століття глибини Чорного моря цікавлять істориків. В 1894 р. перша наукова експедиція в Феодосії (А.Л. Бертьє-Делагард) відкрила для науки унікальний світ підводної археології Чорноморського басейну. В подальшому дослідження античної Ольвії (Л.П. Коллі, Б.В. Фармаковський, В.І. Деренкін) лише підтвердили виключність Чорного моря як джерела нових знань про стародавні епохи. Залучення в 1920-1930 рр. до досліджень організації НКВС «ЕПРОН» дозволило академіку Р.А. Орбелі провести перше планомірне вивчення античних міст Херсонес, Феодосії, Пантикапеї і Ольвії. Вже тоді були визначені перспективні плани 
розвитку підводної археології, затверджені завдання по створенню гідро-археологічної мапи СРСР і Музею підводних досліджень. В 1950-1960 рр. проведено ряд широкомасштабних підводно-археологічних досліджень 3 використанням легководолазного спорядження і першого спеціального обладнання. Були розроблені перші методики досліджень. В.Д. Блаватським було проведено розширене дослідження акваторії озера Донузлав, Ольвії і Херсонесу. В цей час підводна археологія сформувалася як автономний розділ археологічної науки, отримала свою теоретичну і науково-методичну основу. Перші дослідження українських археологів були проведені в 60-х роках в акваторії Ольвії (Харківський університет спільно з Херсонеським заповідником), і біля острова Березань (В.В. Лапін). Фактично, становлення української підводної археології, і зайняття нею головних позицій в галузі, відбулося в 1970-1980 pр.

Найбільш значними роботами українських вчених стали дослідження підводної частини Ольвії (С.Д. Крижицький), акваторій західного узбережжя Чорного моря і Придністров’я (М.В. Агбунов), району островів Березань і Тендрівська коса (В.В. Назаров), узбережжя м. Судак (I.I. Баранов), району озера Донузлав (В.Н. Таска$\epsilon B$, С.І. Симонюков), затопленої частини античного міста Акра в Керченській протоці (К.К. Шилик, А.Н. Шамрай). 31967 р. проводяться регулярні дослідження акваторії р. Дніпро в районі острова Хортиця (Г.І. Шаповалов). В кінці 1980-х — на початку 1990-х рр. Одеським археологічним музеєм було проведено цикл підводних розвідок акваторії острова Зміїний (С.Б. Охотніков, А.С. Островерхов). В 1999 р. Експедицією підводних археологічних робіт (Національний заповідник «Хортиця») було здійснено перший підйом затонулого корабля - військового вітрильно-гребного судна типу «дубель-шлюпка» часів першої Російсько-турецької війни (В.В. Нефьодов, М.А. Остапенко, Д.Р. Кобалія). Велика робота була проведена експедицією Київського Національного університету імені Тараса Шевченка (С.М. Зеленко) на шельфі в районі м. Судак і смт. Новий Світ (АР Крим).

В 2001-2004 рр. Інститутом археології НАН України було проведено цикл підводних досліджень акваторій островів Тендрівська коса, Довгий, Круглий, Джарилгач (В.В. Назаров, С.О. Воронов). В 2004 р. проведено підйом плавзасобу XVIII ст. типу «бригантина» (Д.Р. Кобалия, В.В. Нефьодов). В роботі підводних археологів розпочато широке використання гідролокаторів бокового обзору, ехолотів і металодетекторів.

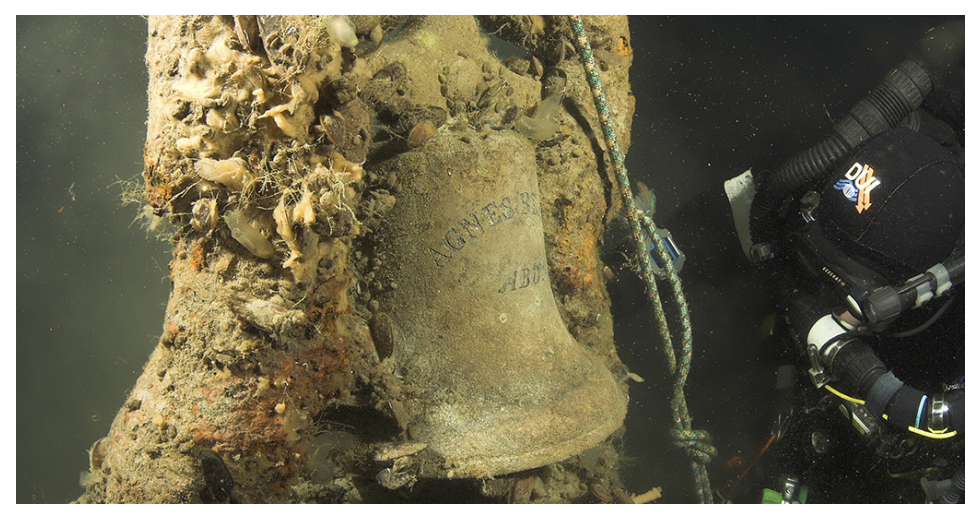

Фото 2. Протитуманна ринда на барку «Agnes Blaikie» Експедиційного флоту Великобританії в Криму (1855 р). Глибина 76 м. Виявлений на зовнішньому рейді Балаклавської бухти. Фото А. Бикова. 
Період активного розвитку підводної археології в Україні розпочався в 2004 2005 рр. Інститутом археології було розпочато створення сучасної законодавчої і методичної бази підводно-археологічних досліджень в Україні. Верховною Радою прийняті Закони «Про охорону культурної спадщини», «Про охорону археологічної спадщини» i ратифікована Європейська конвенція про охорону археологічної спадщини. Україна однією з перших морських держав ратифікувала Міжнародну Конвенцію про охорону підводної культурної спадщини ЮНЕСКО. Конвенція ЮНЕСКО фактично стала першим законодавчим актом, який декларував — Україна має велику морську історію і безцінну підводну спадщину, яку необхідно досліджувати і зберігати для нащадків. Уряд України прийняв Постанову «Про затвердження Порядку видання дозволів на проведення археологічних розвідок, розкопок, інших земляних робіт на території пам'ятників, охоронюваних археологічних територіях, в зонах охорони, в історичних ареалах населених міст, а також досліджень слідів життєдіяльності людей, що знаходяться під земною поверхньою, під водою на теритоpiї України». При розробці законодавчих актів були використані загальносвітові досягнення в організаційних і технічних сфеpax забезпечення підводних досліджень. Суттєво розширилися хронологічні межі діяльності вчених. Законом «Про охорону культурної спадщини» до компетенції археологів були включені об'єкти і пам'ятки XVIII, XIX і XX століть по Другу світову війну включно. 3 ініціативи українських вчених в міжнародний обіг введено нове поняття - міжнародний морськой меморіал. В водах України затонуло 5 суден, на борту яких загинуло більше людей ніж на «Титаніку». Всі ці судна мають статус братських могил.
В 2004 р. згідно з вимогами Міжнародної конвенції про охорону підводної спадщини ЮНЕСКО, Інститутом археології НАН України створено Департамент підводної спадщини - спеціалізоване державне підприємство, головним завданням якого $\epsilon$ розвиток в Україні підводної археології. Вченими Департаменту створено перший Реєстр об’єктів підводної культурної спадщини України, і морська мапа «Пам’ятники підводної культурної спадщини України». Всі відомі і відкриті на той момент об'єкти від неогену до новітньої історії були взяті на державний науковий облік. В Реєстрі i на мапі вперше зафіксовані всі об'єкти археології і історії, які знаходяться в виключній /морській/ економічній зоні, територіальному морі і внутрішніх водах України. В 2005 р. на облік взято 2103 об'єктів, які представляють культурну спадщину Чорноморо-Азовського морських басейнів і Дніпровсько-Дунайської річкових систем. Вченою Радою Інституту археології затверджена «Методика досліджень підводної спадщини України». Створена Інспекція археологічного надзору ДПС, яка діє згідно 3 делегованими Державною службою 3 питань національної спадщини України повноваженнями.

32005 р. Вченою радою Інституту археології НАН Україні затверджується щорічна Програма досліджень підводної спадщини України, яка містить комплекс робіт, направлених на пошук пам'ятників, вивчення, паспортизацію, картографування, консервацію, реставрацію і музеєфікацію. В 2005 р. археологами вперше було здійснено підйом з річки затонулого під час Другої світової війни танка виробництва США «Шерман»-«М-4» (С.О. Воронов). В 2006 р. Департаментом було ініційовано створення комплексу Морського музею України в мм. Севастополі, Києві і Керчі. В технологічний процес досліджень впер- 
ше були включені телекеровані підводні апарати і автономні населені підводні апарати. В ході досліджень було отримано досвід робіт з не традиційними для археології артефактами і пам'ятниками (озброєнням і технікою XIX і XX ст). В 2006 р. археологами 3 глибини 32 м. (Каркінітська затока, Чорне море) був піднятий літак штурмовик «Іл-2», збитий в 1944 р. 3 затонулого в 1917 р. біля острова Зміїний на глибині 36 м есмінця «Лейтенант Зацаренный» була піднята бібліотека командира і комплекс корабельного шпиталю. В прибережній смузі в м. Одеса були виявлені кістки великих савців меотичного ярусу неогену, які попередньо ідентифіковані як розрізнені, фрагментовані частини кісток скелетів гіппаріона і хілатерія (попереднє датування: 7-8 млн. років).

До 2006 р. основна частина відомих затонулих пам'ятників археології i iстоpiї була розташована в прибережній смузі, в місцях найбільш небезпечних 3 точки зору мореплавання. За інформацією Морського гідрофізичного інституту, хвильові процеси в штормових умовах руйнують всі об'єкти, які знаходяться на донній поверхні до глибин 20 м. Враховуючи, що майже 90\% пам'ятників, 3 якими на той час працювали археологи - це залишки античних міст або плавзасобів які затонули на глибині в середньому 10 м, висновок достатньо сумний - вчені приречені працювати 3 максимально пошкодженими або знищеними артефактами. Це перший фактор, який вимагав, в буквальному сенсі, поглиблення робіт в Чорному морі. Наявність в Чорному морі сірко-водневого шару, дає шанс виявлення на глибинах його існування добре збережених пам'ятників навіть античної епохи.

Процес освоєння археологами великих глибин привів до сенсаційного результату. В ході досліджень 2006-2008 рр. в співробітництві з вченими США і Федеративної Республіки Німеччини (міжнародні експедиції «Чорне море-2006», «Візантія-2007» і 3-я глибоководна експедиція) проведених на глибинах від 100 до 2190 м, за дві неділі було виявлено 531 не відомий науці об’єкт. В ході попереднього обстеження 17 з них виявилися цінними і унікальними пам'ятниками середньовіччя і новітньої історії. Вчені зрозуміли - перед ними безцінні скарби науки і культури в недоторканості збережені морем.

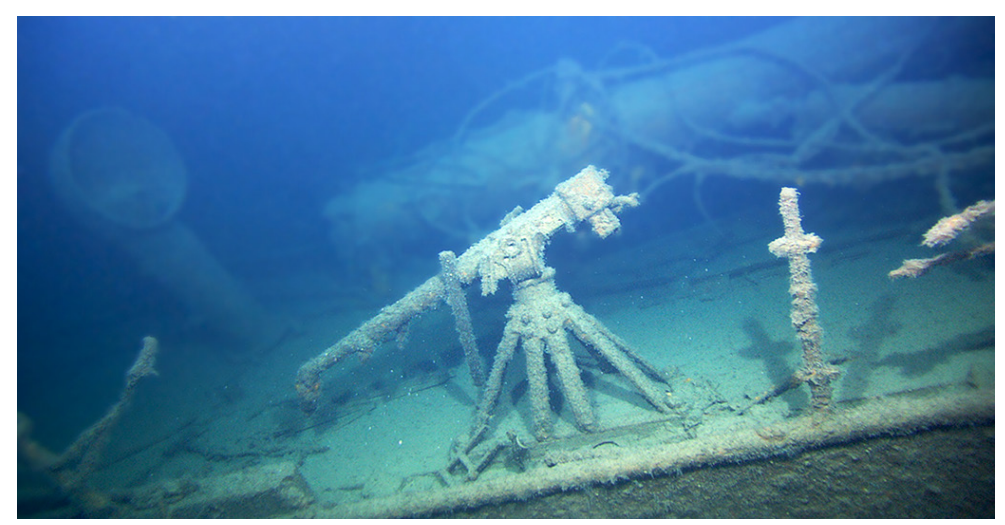

Фото 3. Ескадрений міноносець «Дзержинский» (центральна частина правого борту).

Виявлений Українсько-Американською експедицією «Чорне море-2006» (С. Воронов, Р. Баллард). Фото С. Воронова.

Літом 2009 р. успішно пройшло випробування першого українського телекеро- ваного підводного апарату «Софокл 1». Тепер Україна в одному ряду з країнами 
високих технологій в сфері підводної робото-техніки. Створений вченими Національного університету кораблебудування імені адмірала Макарова, під керівництвом д-ра техн. наук, професора Блінцова В.С. підводний апарат-робот успішно пройшов випробування в ході яких був обстежений шельф Чорного моря на глибинах до 140 м в районі південного берега АР Крим. Саме в результаті цих експедицій були відкриті «Фороський Візантійський корабель» i «Гринівська бригантина».

9 серпня 2009 року в історії досліджень Чорного моря зафіксовано факт відкриття найвідомішого об'єкту: на глибині 126 м в сірко-водневому шарі, виявлений практично цілий середньовічний корабель епохи Візантії (пізніше введений в науковий обіг під назвою «Фороський корабель»). Його відкриття - результат тісного співробітництва археологів і суднобудівників. Локальне місце катастрофи цього корабля було виявлено в ході випробувань ТПА «Софокл-1», за 20 км на S від мису Форос. Порівняно 3 раніше відкритим в 2006 р. візантійським торговим кораблем (малим латинським вітрильником), це було гігантське судно. Загальна візуально зафіксована довжина судна складала біля 36 м. Враховуючи, що носова і кормова частини знищені часом, можливе припущення, що загальна довжина судна була біля 50 м. Приблизна ширина біля 7 м. В ході обстеження апарат зумів 3 допомогою маніпулятора підняти на поверхню невелику дошку, фрагмент бортової обшивки. В результаті радіо-вуглецевої експертизи, проведеної Київською радіо-вуглецевою лабораторією Інституту геохімії оточуючого середовища, було отримано попереднє датування життєдіяльності виявленого судна: 1020-1190 роки. Вірогідніше за все корабель належав Візантії. Не виключено, що він міг належати одній з Італійських республік: Генуї, Пізі чи Венеції. Вірогідний тип корабля: нав, кокк чи велика галера. В ході візуального обстеження місця корабельної катастрофи роботом зафіксовано, що останки корабля збережені на 70\%. Телекамери робота побачили добре збережені фрагменти суднового набору (шпангоути, бімси, стрінгери), палубні дошки, дошки обшивки, частину фор-штевня, біля 15 весел в уключинах, щогли, реї, вантаж амфор в кількості біля 20 шт., які належать до широко розповсюдженого в Причорномор'ї середньовічному типу (грушовидні амфори з дугосхожими ручками), і значна кількість не ідентифікованих предметів. В районі напів-баку був зафіксований вертикально стоячий металевий стрижень с трьома отворами в верхній його частині (вірогідно флаг-шток або веретено якоря). Весла видні лише по правому борту. Щогла покладена вздовж лівого борту. Чітко видно частину кільової дошки i фрагменти планширя лівого і правого бортів. Палуба занесена мулом на $65 \%$.

2009 р. ознаменувався консолідацією наукових і державних установ і відомств в питаннях створення ефективних механізмів збереження підводної спадщини. Наказом Міністерства культури і туризму в Державний реєстр нерухомих пам'ятників України, в категорію пам'ятників місцевого значення, включені перші 18 підводних об'єктів. Це перші українські підводні пам'ятники взяті державою під охорону, які офіційно отримали юридичний статус підводних об'єктів культурної спадщини України.

Щорічно Департаментом проводилося до 20 експедицій. 32009 року розпочали роботу підводно-археологічні експедиції в Національних заповідниках «Херсонес Таврійський» (Р.Н. Рейда) і «Ольвія» (В.В. Вахонєєв). Проведені глибоководні розкопки Візантійського корабля біля мису Херсонес і літака Люфтваффе «Јu-52» під 
Одесою. Здійснено п'ять експедицій по пошуку санітарного транспорта «Армения» і лінійного турецького корабля «Капуданіе».

2010 р. відкрив нову сторінку в вивченні історії Чорного моря. Зроблені виключно цікаві відкриття в археології і історії, в результаті яких вчені суттєво розширили наші знання про Чорне море. Згідно з рішенням конференції 1-ї Міжнародної конвенції про охорону підводної культурної спадщини, спільно з Національним заповідником «Херсонес Таврійський» розпочато створення Музею підводної археології України. На території Національного заповідника «Херсонес Таврійський» з 2009 року створена Головна база підводної археології України.

В 2011 р. при підтримці Національної академії керівних кадрів культури і мистецтв Міністерства культури України (ректор, доктор філософії, професор Чернець В.Г.) Департамент вніс до Закону України «Про державну прикордонну службу» повноваження про охорону підводної спадщини.

В 2012 р., за ініціативою вчених Департаменту підводної спадщини, в Криму було створено Кримську республіканську установу «Чорноморський центр підводних досліджень». Вченими Центру в Міжнародному дитячому центрі «Ар- тек» створено музей «Скарби Чорного моря», основана Міжнародна дитяча академія підводної археології. При підтримці художників-реставраторів Реставраційної майстерні Національного музею історії України (професор Менжулін А.І.) при таборах «Лісовий» і «Озерний» створено лабораторію по реставрації підводних пам'ятників (завідуюча Воронова О.А.). На території «Артека», 3 використанням законсервованих об'єктів періоду Кримської війни (артилерійська гармата і два якоря) встановлені три пам'ятника. На базі Пам'ятника архітектури Національного значення «Дача Стамболі» (м. Феодосія) створена єдина в Україні лабораторія по консервації і реставрації підводних знахідок. Експедиції 2012-2013 pp. постійно поповнювали музейні фонди «Артека» i Феодосійського виставково-музейного центру підводної археології. Серед самих відомих робіт Центру — відкриття самого стародавнього затонулого в Чорному морі плавзасобу - античного корабля $\mathrm{V}$ ст. до н. е. (акваторія Кінбурнської коси в Миколаївській обл.), розкопки затонулої частини античного міста Акра (Вахонєєв В.В.), і виявлення пропалого безвісти в 1944 р. підводного човна ЧЧФ «Щ-216» (акваторія півострова Тарханкут).

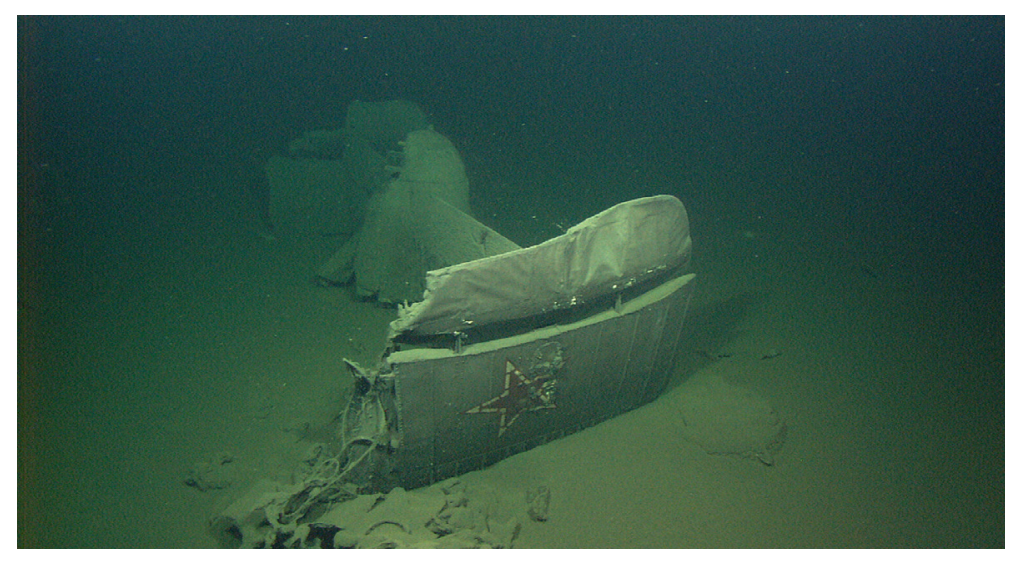

Фото 4. Хвостова частина протичовнового гелікоптера «К-25Ц» ВПС СФ ВМФ СРСР (впав у 1982 році). Виявлений Українсько-американською експедицією «Чорне море-2006» (С. Воронов, Р. Баллард). Фото С. Воронова 
В 2014 р. в зв’язку з окупацією Криму призупинила свою офіційну діяльність єдина в Україні державна установа, яка займалася питаннями підводної спадщини - Чорноморський центр підводних досліджень. На 1.02.2019 р. залишаються недоступними 49\% берегової смуги України і 51\% пам'ятників (безпосередньо акваторія АР Крим). Ситуація в питанні збереження цих об'єктів характеризується як не керована. Правоохоронними органами фіксуються факти розграбування і не санкціонованого підйому підводних пам'ятників. Головні державні музейні заклади, присвячені морській історії України залишилися в Криму (мм. Феодосія, Севастополь і Балаклава). В результаті окупації Україна втратила доступ до всіх колекцій і експозицій цієї тематики.

В 2015 р. розвиток підводно-археологічних досліджень в Україні продовжує Науково-дослідний інститут пам'ятникоохоронних досліджень Міністерства культури України. 32006 по 2015 рік п'ять офіційних делегацій України в Конвенції ЮНЕСКО «Про охорону підводної культурної спадщини» активно популяризували досягнення української науки, вносили пропозиції про удосконалення механізму збереження підводної спадщини. Вчені «Чорноморського центру підводних досліджень» приймають участь, як експерти і свідки, в роботі слідства Міжнародного трибуналу (м. Гаага) по арбітражному провадженні 3 метою захисту прав прибережної держави в прилеглих до Криму морських зонах в Чорному та Азовському морях і Керченській протоці.

В 2017 р. вчені, при підтримці Комітету Верховної Ради України з питань культури і духовності (заступник голови Комітету, голова підкомітету з питань державної політики в сфері свободи совісті і релігійних організацій Єленський В.С.,) ініціювали
Закон України від 8 січня 2018 р. № 2289VIII «Про внесення змін в Закон Украины «Про охорону культурної спадщини» (про надання об'єктам підводної культурної спадщини статусу Морського меморіалу)».

З 2017 по 2018 рр. Центральним військово-морським музеєм України в ході експедицій було обстежено $75 \%$ донної поверхні акваторії Північного Причорномор'я (територіальні води яких прилягають до узбережжя Миколаївської і Херсонської областей) і виключної економічної зони України в районах Каркінітської затоки і Одеської банки. На основі отриманих результатів доповнена мапа розташування об’єктів підводної культурної спадщини України. Всього, додатково, на донній поверхні виявлено ще 507 об'єктів, 3 них 15 попередньо ідентифіковані. Серед них є об'єкти, які можуть належати палеоліту/ неоліту, античності, середньовіччю (Biзантійська імперія), до подій Російсько-турецьких війн, Першої і Другої світових війн. Серед знахідок не ідентифіковані архітектурні споруди, вітрильні і веслові плавзасоби, цивільні і військові судна і кораблі, катери, різні зразки авіатехніки. Інформація про наявність більшості виявлених об'єктів, які мають відношення до XX ст, отримана 3 фондів Bundesarchiv, Abteilung Militararchiv (Freiburg). Особливу увагу було приділено обстеженню південно-західної частини акваторії острова Тендрівськая коса (Херсонськая обл.), північної частини акваторії острова Березань, Одеської банки і півострова Кінбурнська коса (Миколаївська обл.). По результатам досліджень в 2017 р. вченими-археологами музею розроблений проект створення першого в Чорному морі підводного музею, присвяченого історії Військово-морського флоту в XX ст. під назвою «Морськой парк Тендрівський». 
Значну роль в розвитку глибоководного потенціалу підводної археології України відіграло міжнародне співробітництво. В рамках спільного проекту Збройних сил України (Управління цивільно-військового співробітництва) і Уряду США (Дирекції Європейсько-Середземноморського регіону місії Агенства по захисту військовополонених) проводиться розслідування загибелі літака ВПС США над Чорним морем під час Холодної війни. Висотний, стратегічний літак-розвідник «Martin B-57f Canberra» (ідентифікаційний № 63-13287) пропав 14 грудня 1965 р. Літак вилетів на виконання завдання, але на базу в призначений час не повернувся. На сьогодні в США діє державна програма пошуку загиблих громадян країни, в рамках якої Центральним військово-морським музе$\epsilon м$ України здійснюється пошук залишків екіпажу літака. 1 грудня 2018 р. завершено перший етап операції. Вченим вдалося локалізувати три квадрати вірогідного місця падіння «RB-57f». Дякуючи експедиції створена необхідна матеріально-технічна база, яка дозволить проведення результативних пошукових робіт, під час яких буде задіяно науково-дослідне судно $\mathrm{CC}$ «Oceania». Кінцева мета проекту — виявлення частини фюзеляжу з кабіною пілотів і підйом останків членів екіпажу для захоронення в США.

ЦВММУ позиціює себе не лише як склад морських експонатів і пов'язаною 3 ними інформації, але й як справжній дослідний центр, який займається вивченням морів і підготовкою експедицій. В 2020 р. вченими ЦВММУ завершено формування Наукового реєстру підводної культурної спадщини України, до якого увійшли всі відомі затонулі в водах України рухомі і нерухомі об'єкти і пам'ятники археології i історії. На протязі 2014-2020 pp. істориками акумульовано більшість існуючих, як в Україні так і за кордоном, архівних матеріалів і результатів польових досліджень. В Реєстрі, крім переліку пам'ятників які відносяться до античності і середньовіччя, додатково представлена деталізована інформація про затонулі об'єкти і військову техніку часів Першої і Другої світових війн і Громадянської війни в СРСР. Робота містить об'єктивну, багатосторонню і максимально повну фактологічну базу. Представлено інформацію про всі відомі затонулі в водах нашої країни об'єкти: поселення і міста, військові кораблі і катери, цивільні судна, військово-повітряну техніку і бронетехніку. Інформація про кожен об'єкт містить: історичну (архівну) довідку, технічні характеристики, матеріали останніх досліджень, картографічну інформацію. В переліку зафіксовано лише об'єкти, інформація про які підтверджена, як мінімум, з двох державних незалежних джерел. Об'єкти є важливими історичними свідченнями подій минулого на території України.

Всього до Ресстру включено: 2063 пам’ятки (по факту на 29.III.2020 р.).

\section{Географічний поділ:}

Акваторія Чорного моря: 1692 об'єкт;

Акваторія Азовського моря: 161 об'єкт;

Акваторія р. Дніпро та Дніпровської водної системи: 106 об'єктів;

Акваторія р. Дунай та Дунайської водної системи: 109 об'єктів;

\section{Історичний поділ:}

Період після 2-ї Світової війни: 37 об’ єктів;

2-га Світова війна: об’єктів; 1595 об'єктів;

Громадянська війна в СРСР: 55 об'єктів;

1-ша Світова війна: 31 об'єкт;

Російсько-Турецькі війни - Кримська війна - початок XX ст.: 264 об'єкти; 
Середньовіччя: 23 об’єкти;

Антична епоха: 51 об'єкт;

Піздній плейстоцен, залишки пізньопалеолітичного поселення: 1 об'єкт;

Меотичний ярус неогену: 1 об'єкт;

Після окупації Криму на базі ЦВММУ заново формується єдина в Україні спеціалізована лабораторія по консервації і реставрації піднятих з води артефактів. Ряд вчених ЦВММУ отримав великий досвід робіт на базі Інституту археологічної океанографії Університету Род Айленд, США (директор Р.Д. Баллард). Історики пройшли навчання на операторів телекерованих підводних апаратів "Seaeye Panter XT-1500" (Великобританія), і пілотів глибоководних населених підводних апаратів "C-Explorer 3" виробництва Нідерландів, і здійснили навчальні занурення на острові Мальта. Обидва апарати дозволяють безпечно проводити підводно-археологічні і гідротехнічні роботи на великих глибинах.

Без перебільшення - Чорне море унікальне місце, повне пам'ятників міжнародного значення, які вимагають термінових підводно-археологічних досліджень. А значить вчених чекає сама цікава в світі робота - писати історію. I попереду таємниці затонулих міст і кораблів, наукові відкриття i сенсації. Великий музей під назвою «Чорне море» чекає. И ми чудово розуміємо що двері до нього лише привідкриті. 